\title{
SINTESIS DAN MIKROENKAPSULASI PENSUBSTITUSI LEMAK AIR SUSU IBU (PLASI) BERBAHAN MINYAK SAWIT
}

\author{
[Synthesis and Microencapsulation of Palm Oil Based Human Milk Fat Substitute]
}

\author{
Hasrul Abdi Hasibuan* dan ljah \\ Kelompok Peneliti Pengolahan Hasil dan Mutu, Pusat Penelitian Kelapa Sawit (PPKS), Medan \\ Diterima 20 Oktober 2016 / Disetujui 14 Desember 2016
}

\begin{abstract}
This study was aimed to evaluate human milk fat substitute (HMFS) synthesized from a mixture of palm stearin, palm kernel oil, soybean oil, olive oil and tuna fish oil at ratios of 2.9:3.4:1.5:2.0:0.2, respectively. The oil blend was interesterified using $10 \%$ of lipase as a catalyst at $60^{\circ} \mathrm{C}$ for $2,4,6,8,12$ and $24 \mathrm{~h}$. The fatty acid composition, melting point and solid fat content of the resulting products were characterized. Fitteen to thirty percent of HMFS were microencapsulated using matrix of skim milk, maltodextrin and lactose at a ratio of 1:1:1. The melting point of the oil blend decreased following interesterification for the optimum reaction time of $4 \mathrm{~h}$ and the attained melting point of HMFS was $28^{\circ} \mathrm{C}$. Different skim milk solubilty levels influenced the quality of the resulting microcapsules. The concentration of HMFS affected microcapsul yield, encapsulation eficiency and solubility in water. Microencapsulation of HMFS at concentration of $25 \%$ using matrix of skim milk, maltodextrin and lactose produced higher yield and encapsulation efficiency than that of 15,20 and $30 \%$.
\end{abstract}

Keywords: milk fat substitute, microencapsulation, palm kernel oil, palm oil

\section{ABSTRAK}

Penelitian ini bertujuan untuk mengevaluasi pensubstitusi lemak air susu ibu (PLASI) yang disintesis dengan menggunakan campuran stearin sawit, minyak inti sawit, minyak kedelai, minyak zaitun dan minyak ikan tuna pada nisbah 2,9:3,4:1,5:2,0:0,2. Campuran minyak diinteresterifikasi dengan katalis enzim lipase $10 \%$ terhitung dari substrat pada suhu $60^{\circ} \mathrm{C}$ selama variasi waktu 2, 4, 6, 8, 16 dan 24 jam. Komposisi asam lemak, titik leleh dan kandungan lemak padat produk PLASI kemudian dikarakterisasi. Selanjutnya, produk PLASI sebanyak 15-30\% dimikroenkapsulasi dengan menggunakan bahan penyalut yaitu susu skim yang dicampur dengan maltodeks trin dan laktosa pada nisbah 1:1:1. Didapatkan bahwa titik leleh campuran minyak menurun setelah interesterifikasi dengan waktu reaksi optimum 4 jam dan pada kondisi tersebut diperoleh PLASI dengan titik leleh sebesar $28^{\circ} \mathrm{C}$. Penggunaan susu skim pada tingkat kelarutan yang berbeda berpengaruh terhadap kualitas mikrokapsul yang dihasilkan. Jumlah PLASI juga berpengaruh terhadap perolehan mikrokapsul, efisiensi enkapsulasi dan kelarutan dalam air. Mikroenkapsulasi PLASI sebanyak 25\% dengan menggunakan matriks susu skim, maltodekstrin dan laktosa menghasilkan perolehan mikrokapsul dan efisiensi enkapsulasi yang lebih tinggi dibandingk an pada konsentrasi penggunaan 15, 20 dan $30 \%$.

Kata kunci: pensubstitusi lemak air susu ibu (PLASI), mikroenkapsulasi, minyak inti sawit, minyak sawit

\section{PENDAHULUAN}

Susu merupakan salah satu elemen penting bagi makanan manusia karena mengandung sumber nutrisi yang lengkap dan seimbang meliputi lemak, protein, gula, vitamin dan mineral (Lubary et al., 2011) sehingga sangat bermanfaat bagi kesehatan sejak bayi hingga dewasa (Nikkhah, 2012). Khusus untuk bayi, susu terbaik yang diberikan adalah air susu ibu (ASI) namun karena satu dan

${ }^{*}$ Penulis Korespondensi:

E-mail: hasibuan_abdi@yahoo.com lain hal seperti kesibukan dalam pekerjaan, ASI mulai tergantikan dengan susu formula (Purwanti et al., 2009; Djajasoepena et al., 2015). Lemak ASI menyuplai fraksi tertinggi dari kebutuhan energi bayi (Sahin et al., 2005 a ; Sahin et al., 2006). Lemak ASI mengandung asam lemak jenuh yaitu laurat, miristat dan palmitat (El-Salam, 2015) dan asam lemak tidak jenuh meliputi asam oleat, linoleat, asam linolenat, asam eikosapentanoat (eiscosapentanoic acid, EPA) dan asam dokosaheksanoat (docosahexanoic acid, DHA) (Yadong dan Guicheng, 2011). ASI juga mengandung colostrum yang merupakan salah satu 
jenis vitamin dengan kandungan senyawa $\beta$-karoten (Goedhart dan Bindles, 1994).

Kebutuhan susu formula semakin meningkat sehingga alternatif lemak susu yang disebut dengan pensubstitusi lemak air susu ibu (PLASI) perlu dikembangkan. Sintesis PLASI dapat dilakukan dengan menggunakan minyak/lemak nabati (Lubary et al., 2011) dan/atau campurannya dengan lemak hewani (Maduko et al., 2007). Menurut Oboh (2012) bahwa lemak ASI memiliki profil pelelehan yang baik dan mencair sempurna pada suhu tubuh. Oleh karena itu, minyak nabati penggantinya juga harus memiliki profil pelelehan yang menyerupainya. Untuk memodifikasi campuran minyak dan lemak diperlukan proses interesterifikasi enzimatis. Proses ini menggunakan katalis enzim lipase untuk mengubah komposisi trigliserida lemak menjadi terstruktur. Khusus untuk PLASI, modifikasi dilakukan agar komposisinya menyerupai lemak ASI (Sahin et al., 2005).

Beberapa peneliti telah melaporkan pensintesisan PLASI menggunakan minyak nabati. Maduko et al. (2007) mensintesis PLASI melalui interesterifikasi campuran tripalmitat, minyak kelapa, minyak biji bunga dan minyak kedelai menggunakan Lipozyme kemudian dicampurkan dengan lemak dari susu hewani. Karabulut et al. (2007) mensintesis PLASI melalui interesterifikasi campuran minyak sawit, minyak inti sawit, minyak zaitun, minyak bunga matahari dan minyak ikan dari laut menggunakan lipase Thermomyces lanuginosa (Lipozyme TL IM). Nielsena et al. (2006) mensintesis PLASI yang mengandung asam gamma linoleat melalui interesterifikasi antara tripalmitat, asam lemak dari minyak hazel dan asam gamma linoleat dalam heksan dengan lipase spesifik 1,3 Lipozyme RM IM dan Lipozyme TL IM. Karow et al. (2012) mensintesis PLASI yang mengandung asam laurat tinggi melalui interesterifikasi minyak kelapa dan stearin sawit secara enzimatis. Untuk memperkaya dan meningkatkan stabilitas PLASI dapat ditambahkan antioksidan seperti tokoferol (Maduko et al., 2007).

Stearin sawit merupakan fraksi padat minyak sawit yang mengandung asam palmitat tinggi $(57,3-$ $66,7 \%$ ) (Hasibuan, 2012). Selain itu, minyak inti sawit mengandung asam lemak rantai menengah berupa asam laurat tinggi (47,6-54,3\%) (Hasibuan et al., 2012). Minyak sawit juga mengandung senyawa fitonutrien meliputi karoten sebagai provitamin A dan tokoferol dan tokotrienol sebagai vitamin E (Hasibuan dan Siahaan, 2014). Dengan demikian, penggunaan minyak sawit sebagai alternatif untuk sintesis PLASI sesuai karena ragam nutrisi yang dimilikinya cukup lengkap. Koo et al. (2006) juga menyatakan hal yang sama bahwa minyak sawit sangat sesuai digunakan untuk substitusi lemak susu dalam formula susu untuk bayi.
Mikroenkapsulasi merupakan proses penyalutan lapisan baik terhadap partikel padatan yang kecil atau droplet dari suatu cairan atau larutan (Levin, 2006). Salah satu proses pembuatan mikroenkapsulat dapat dilakukan dengan menggunakan metode pengeringan semprot yang akan menghasilkan produk bubuk dengan kualitas yang baik (Yanuar et al., 2007). Dalam pembuatan susu formula, mikroenkapsulasi lemak dalam bahan penyalut dapat dilakukan menggunakan alat pengeringan semprot. Pelarut pada campuran emulsi akan terevaporasi setelah mengalami kontak dengan udara pengering dan kemudian terjadi pemisahan partikel kering (Elisabet et al., 2008). Penelitian ini dilakukan untuk mensintesis PLASI melalui interesterifikasi campuran stearin sawit dan minyak nabati lainnya. Selanjutnya, produk PLASI dienkapsulasi menggunakan bahan penyalut yaitu susu skim yang dicampur dengan maltodekstrin dan laktosa. Penggunaan bahan penyalut menjadi penting untuk dikaji karena kestabilan emulsi minyak dipengaruhi oleh bahan penyalut.

\section{BAHAN DAN METODE}

\section{Bahan}

Bahan yang digunakan pada penelitian ini adalah stearin sawit dan minyak inti sawit yang diperoleh dari PT. Wilmar Internasional (Medan, Indonesia). Minyak kedelai dan minyak zaitun diperoleh dari swalayan. Minyak ikan tuna diperoleh melalui ekstraksi dari ikan tuna. Susu skim yang digunakan dua jenis yaitu susu skim merek A (SSA) dan susu skim merek B (SSB) yang dibedakan berdasarkan harga dan kualitas fisik atau warna yang diperoleh dari 2 Toko Bahan Kue (Medan, Indonesia). Tween 80, maltodekstrin DE 10-15 dan laktosa diperoleh dari Toko Bahan Kimia (Medan, Indonesia).

\section{Sintesis lemak air susu ibu (PLASI)}

Sintesis PLASI dilakukan dengan menggunakan campuran minyak nabati meliputi stearin sawit, minyak inti sawit, minyak kedelai, minyak zaitun dan minyak ikan tuna dengan nisbah campuran yaitu 2,9:3,4:1,5:2,0:0,2 yang telah disesuaikan dengan karakteristik PLASI yang dihasilkan oleh Karabulut et al. (2007). Sebanyak $10 \mathrm{~g}$ campuran lemak diinteresterifikasi dengan penambahan $1 \mathrm{~g}$ Novozyme 435 (Novozymes A/S, Denmark) dan diaduk dengan kecepatan $300 \mathrm{rpm}$ dengan pemanasan menggunakan alat pemanas (Thermo Scientific, Jerman) pada $60^{\circ} \mathrm{C}$ selama variasi waktu yaitu $2,4,6,8,16$ dan 24 jam. Setelah reaksi tercapai campuran disaring menggunakan kertas saring Whatman No. 42 untuk memisahkan katalis. Produk dianalisa meliputi kadar 
monogliserida, digliserida dan trigliserida (MG-DGTG), kadar asam lemak bebas (ALB), titik leleh dan komposisi asam lemak.

\section{Mikroenkapsulasi PLASI}

PLASI dinetralisasi untuk menghilangkan ALB menggunakan larutan natrium hidroksida $0,1 \mathrm{~N}$ (Merck, Jerman) sesuai dengan jumlah ALB yang dikandungnya. Campuran dipanaskan menggunakan alat pemanas pada suhu $50^{\circ} \mathrm{C}$ selama $15-30$ menit. Setelah waktu tercapai produk dicuci menggunakan air hingga diperoleh produk bebas dari natrium hidroksida yang ditandai dengan air cucian produk tidak berubah warna menjadi merah muda ketika ditambahkan dengan indikator phenolfthalein.

Selanjutnya, mikroenkapsulasi PLASI dilakukan dengan menggunakan bahan penyalut susu susu skim yang dicampur dengan laktosa dan maltodekstrin pada nisbah 1:1:1. Susu skim yang digunakan adalah susu skim $A$ dan susu skim $B$ sehingga perlu dikaji penggunaannya sebagai bahan penyalut dalam pembuatan mikrokapsul untuk susu formula yang mengandung lemak PLASI. Jumlah lemak PLASI yang digunakan sebanyak 15, 20, 25 dan $30 \%$ terhadap berat seluruh campuran dalam pembuatan susu formula. Emulsifier yang digunakan adalah Tween 80 dengan jumlah sebanyak $1 \%$ dari PLASI. Campuran antara susu skim, laktosa, maltodekstrin dilarutkan dengan air bersuhu $50-60^{\circ} \mathrm{C}$ dengan konsentrasi $30 \%$ (b/b). PLASI dan emulsifier ditambahkan ke dalam campuran dan dihomogenisasi. Selanjutnya campuran dimikroenkapsulasi menggunakan alat pengeringan semprot (Buchi, Swiss) dengan laju umpan $15 \mathrm{~mL} /$ menit pada suhu inlet $180^{\circ} \mathrm{C}$ dan outlet $80^{\circ} \mathrm{C}$. Produk yang dihasilkan kemudian dianalisa meliputi efisiensi enkapsulasi (Elisabeth et al., 2003), kadar air (AOAC, 1997) dan kelarutan produk mikrokapsul (Fardiaz, 1992).

\section{Analisa kandungan gliserida}

Analisis kandungan gliserida (monogliserida (MG), digliserida (DG), trigliserida (TG)) dan ALB dilakukan dengan mengadopsi prosedur dalam Siahaan et al. (2008) menggunakan kromatografi lapis tipis pada plat yang dilapisi dengan silika gel 60 (Merck). Plat dikembangkan dengan pelarut petroleum eter/dietil eter/asam asetat $(90: 10: 1 \mathrm{v} / \mathrm{v} / \mathrm{v})$ (Merck), serta visualisasi spot dilakukan dengan $\begin{array}{llll}\text { penyemprotan } \quad 2 ', 7^{\prime} \text {-diklorofluoresens } \quad 0,2 \% & (\mathrm{~b} / \mathrm{v})\end{array}$ dalam etanol. Kandungan MG, DG, TG dan ALB dihitung berdasarkan berat relatif masing-masing fraksi.

\section{Analisa komposisi asam lemak}

Analisa komposisi asam lemak mengacu metode standar AOCS Official Method Ce 1b-89 (AOCS, 1998) menggunakan alat kromatografi gas (GC-2010, Shimadzu, Jepang). Sebanyak 0,025 g sampel ditambahkan $1,5 \mathrm{~mL} \mathrm{NaOH}$ metanolik $0,5 \mathrm{~N}$ (Merck). Campuran kemudian dipanaskan dalam penangas air pada $80^{\circ} \mathrm{C}$ selama 5 menit. Campuran didinginkan kemudian ditambahkan $2 \mathrm{~mL}^{\mathrm{B}} \mathrm{BF}_{3}$ metanol $(14 \% \mathrm{~b} / \mathrm{v})$ (Merck) dan dipanaskan kembali dalam penangas air pada $80^{\circ} \mathrm{C}$ selama 30 menit. Campuran didinginkan kemudian ditambahkan $1 \mathrm{~mL}$ isooktana (Merck) dan diaduk selama 1-2 menit. Campuran ditambahkan $5 \mathrm{~mL} \mathrm{NaCl}$ jenuh (Merck) dan diaduk. Lapisan isooktana dipisahkan dan dipindahkan ke dalam vial lalu diinjeksikan sebanyak $0,1 \mu \mathrm{L}$ ke dalam kromatografi gas (GC-2010, Shimadzu). Kolom yang digunakan dalam analisa komposisi asam lemak adalah DB-23 (J\&W Scientific, Amerika Serikat). Kondisi operasi kromatografi gas adalah suhu detektor $260^{\circ} \mathrm{C}$, suhu injektor $260^{\circ} \mathrm{C}$. Temperatur oven terprogram dengan kondisi awal $70^{\circ} \mathrm{C}$, kemudian dinaikkan sebesar $20^{\circ} \mathrm{C} /$ menit hingga $180^{\circ} \mathrm{C}$, kemudian naik $1^{\circ} \mathrm{C} /$ menit hingga $182^{\circ} \mathrm{C}$, kemudian naik $10^{\circ} \mathrm{C} /$ menit hingga $220^{\circ} \mathrm{C}$ dan ditahan selama 2 menit.

\section{Analisa kandungan lemak padat}

Analisis kandungan lemak padat ditentukan menggunakan alat resonansi magnetik inti (nuclear magnetic resonance, NMR mqone, Bruker, Jerman) dengan mengacu pada metode standar AOCS Official Method Cd 16b-93 (AOCS, 1998). Sampel minyak dicairkan dengan pemanasan dalam penangas air pada suhu $80^{\circ} \mathrm{C}$. Sampel dimasukkan ke dalam 12 tabung untuk analisa kandungan lemak padat dengan ketinggian sampel sekitar $4 \pm 1 \mathrm{~cm}$. Sampel dipanaskan di dalam penangas air pada suhu $100^{\circ} \mathrm{C}$ selama 15 menit kemudian dipindahkan ke penangas air pada suhu $0^{\circ} \mathrm{C}$ selama 60 menit. Selanjutnya, setiap 2 tabung sampel dipindahkan ke penangas air dengan suhu masing-masing 10, 20, $25,30,35,40^{\circ} \mathrm{C}$ selama $30-35$ menit. Kandungan lemak padat setiap sampel pada masing-masing suhu diukur dengan memasukkannya ke dalam lubang untuk tabung analisa kandungan lemak padat pada alat NMR dengan metode Stab AOCS Method. Kalibrasi NMR menggunakan standar kandungan lemak padat $0,31,5$ dan $72,9 \%$.

\section{Analisa titik leleh}

Analisis titik leleh (AOCS Official Methods Cc 325, AOCS, 1998) dilakukan terhadap campuran bahan baku sebelum dan sesudah reaksi interesterifikasi. Sampel dilelehkan dalam penangas air pada suhu $80^{\circ} \mathrm{C}$ dan dimasukkan ke dalam pipa kapiler (3 buah) setinggi $1 \mathrm{~cm}$. Sampel disimpan dalam alat pendingin (Panasonic, Indonesia) pada suhu $4-10^{\circ} \mathrm{C}$ selama 16 jam. Setelah waktu tercapai, pipa kapiler diikatkan pada termometer (Alla, Perancis) dan kemudian dimasukkan ke dalam gelas piala yang berisi sekitar $300 \mathrm{~mL}$ air. Suhu air dalam gelas piala diatur pada suhu $8-10^{\circ} \mathrm{C}$ di 
bawah titik leleh sampel dan suhu air dipanaskan menggunakan alat pemanas secara perlahan (dengan kenaikan $0,5-1,0^{\circ} \mathrm{C} /$ menit) dengan pengadukan. Pemanasan dilanjutkan dan suhu diamati dari saat sampel meleleh sampai sampel naik pada tanda batas atas. Titik leleh dihitung berdasarkan rata-rata suhu dari ketiga sampel yang diamati.

\section{Analisa perolehan enkapsulasi dan efisiensi enkapsulasi}

Perolehan enkapsulasi dan efisiensi enkapsulasi ditentukan dengan mengadopsi prosedur dalam Elisabeth et al. (2003). Efisiensi enkapsulasi menunjukkan jumlah minyak yang terdapat dalam mikrokapsul dan dibandingkan dengan jumlah minyak yang digunakan pada proses mikrokapsul. Ekstraksi minyak pada mikrokapsul dilakukan dengan alat soklet menggunakan pelarut heksan.

\section{Analisa kadar minyak tidak tersalut}

Analisa kadar minyak tidak tersalut dilakukan dengan prosedur dalam Elisabeth et al. (2003). Sebanyak $1 \mathrm{~g}$ mikrokapsul dimasukkan ke dalam tabung sentrifuse bertutup, ditambahkan $15 \mathrm{~mL}$ heksan kemudian divorteks selama 10 menit. Campuran disaring dan supernatan ditampung pada labu evaporator. Kertas saring dicuci dengan heksan dan supernatan kemudian dievaporator vakum. Selisih berat merupakan jumlah minyak yang terdapat pada permukaan mikrokapsul.

\section{Analisa kadar air dan kelarutan dalam air}

Analisa kadar air mengadopsi prosedur AOAC (1997) yaitu sampel sebanyak $2 \mathrm{~g}$ dimasukkan ke dalam cawan aluminium yang telah diketahui beratnya kemudian dimasukkan ke dalam oven pada suhu $105-110^{\circ} \mathrm{C}$ hingga diperoleh berat konstan. Analisa kelarutan dalam air dilakukan menggunakan air suhu $28-30^{\circ} \mathrm{C}$ dan $50-55^{\circ} \mathrm{C}$ mengadopsi prosedur dalam Fardiaz (1992).

\section{HASIL DAN PEMBAHASAN}

\section{Pensubstitusi lemak air susu ibu (PLASI)}

Stearin sawit digunakan sebagai sumber asam palmitat, miinyak inti sawit sumber asam laurat, minyak zaitun sumber asam oleat, minyak kedelai sumber asam linolenat dan minyak ikan tuna sumber omega-3 yaitu DHA dan EPA. Omega-3 adalah asam lemak tidak jenuh ganda yang merupakan nutrisi dan bermanfaat untuk kesehatan yaitu mencegah terjadinya aterosklerosis, trombosis dan tekanan darah tinggi (Puligundla et al., 2012). Campuran antara stearin sawit, minyak inti sawit, minyak kedelai, minyak zaitun dan minyak ikan tuna pada nisbah 2,9:3,4:1,5:2,0:0,2 menghasilkan komposisi asam lemak seperti yang ditunjukkan pada Tabel 1.

Jumlah EPA $(0,1)$ dan DHA $(0,7)$ dalam campuran pada Tabel 1 menyerupai lemak pada ASI. Menurut Saphier et al. (2013) bahwa jumlah DHA pada lemak ASI umumnya berkisar antara 0,1$1,0 \%$ dari total komposisi asam lemak dan variasi perbedaan tergantung pada sumber makanan laut yang dimakan oleh ibu. Nilai ini relatif rendah dibandingkan PLASI yang dihasilkan oleh Sahin et al., (2006) yaitu sebesar 6,2\%. Perbedaan ini disebabkan oleh jumlah minyak ikan yang ditambahkan ke dalam campuran berbeda.

Tabel 1. Komposisi asam lemak bahan baku dan pensubstitusi lemak air susu ibu (PLASI) yang dihasilkan

\begin{tabular}{|c|c|c|c|c|c|c|c|c|}
\hline $\begin{array}{c}\text { Asam } \\
\text { Lemak } \\
(\%)\end{array}$ & $\begin{array}{c}\text { Stearin } \\
\text { Sawit }\end{array}$ & $\begin{array}{l}\text { Miny ak Inti } \\
\text { Sawit }\end{array}$ & $\begin{array}{l}\text { Miny ak } \\
\text { Kedelai }\end{array}$ & $\begin{array}{c}\text { Miny ak } \\
\text { Zaitun }\end{array}$ & $\begin{array}{c}\text { Miny ak Ikan } \\
\text { Tuna }\end{array}$ & Campuran & $\begin{array}{c}\text { Produk } \\
\text { Interesterif ikasi } \\
(4 \mathrm{Jam})\end{array}$ & $\begin{array}{l}\text { Karabulut } \\
\text { et al. (2007) }\end{array}$ \\
\hline $\begin{array}{l}\text { C6:0 } \\
\text { C8:0 }\end{array}$ & - & $\begin{array}{l}0,10 \pm 0,01 \\
3,50 \pm 0,01\end{array}$ & - & - & $\begin{array}{l}- \\
-\end{array}$ & $\begin{array}{l}0,10 \pm 0,01 \\
0,90 \pm 0,01\end{array}$ & $\begin{array}{l}0,10 \pm 0,04 \\
0,90 \pm 0,08\end{array}$ & $\begin{array}{l}0,10 \\
1,50\end{array}$ \\
\hline C10:0 & - & $3,70 \pm 0,05$ & - & - & - & $1,10 \pm 0,05$ & $1,00 \pm 0,12$ & 1,30 \\
\hline $\begin{array}{l}\text { C12:0 } \\
\text { C14:0 }\end{array}$ & $\begin{array}{l}0,10 \pm 0,00 \\
1,20 \pm 0,03\end{array}$ & $\begin{array}{l}50,90 \pm 0,23 \\
15,70 \pm 0,13\end{array}$ & $\begin{array}{l}- \\
-\end{array}$ & $\begin{array}{l}- \\
-\end{array}$ & $4,50 \pm 0,11$ & $\begin{array}{c}18,70 \pm 0,06 \\
6,70 \pm 0,10\end{array}$ & $\begin{array}{c}17,50 \pm 1,42 \\
6,60 \pm 0,22\end{array}$ & $\begin{array}{l}17,80 \\
6,00\end{array}$ \\
\hline C16:0 & $61,70 \pm 0,12$ & $7,30 \pm 0,07$ & $10,00 \pm 0,11$ & $12,30 \pm 0,04$ & $22,10 \pm 0,22$ & $26,70 \pm 0,23$ & $26,90 \pm 0,44$ & 23,0 \\
\hline C16:1 & $0,10 \pm 0,01$ & - & - & $0,80 \pm 0,04$ & $5,10 \pm 0,35$ & $0,20 \pm 0,01$ & $0,20 \pm 0,05$ & 0,30 \\
\hline $\begin{array}{l}\text { C18:0 } \\
\text { C18:1 }\end{array}$ & $\begin{array}{c}4,80 \pm 0,03 \\
26,00 \pm 0,09\end{array}$ & $\begin{array}{c}1,90 \pm 0,06 \\
13,30 \pm 0,12\end{array}$ & $\begin{array}{l}4,00 \pm 0,008 \\
23,00 \pm 0,18\end{array}$ & $\begin{array}{r}2,30 \pm 0,04 \\
72,60 \pm 0,04\end{array}$ & $\begin{array}{r}5,30 \pm 0,12 \\
12,50 \pm 0,21\end{array}$ & $\begin{array}{r}3,20 \pm 0,05 \\
29,90 \pm 0,29\end{array}$ & $\begin{array}{c}3,30 \pm 0,08 \\
30,50 \pm 0,89\end{array}$ & $\begin{array}{c}2,50 \\
31,90\end{array}$ \\
\hline C18:2 & $5,70 \pm 0,05$ & $2,20 \pm 0,02$ & $51,00 \pm 0,25$ & $10,10 \pm 0,04$ & $1,10 \pm 0,04$ & $11,10 \pm 0,12$ & $11,50 \pm 0,34$ & 14,00 \\
\hline C18:3 & $0,10 \pm 0,00$ & $0,10 \pm 0,00$ & $7,00 \pm 0,06$ & $0,40 \pm 0,02$ & $0,60 \pm 0,04$ & $0,90 \pm 0,04$ & $1,00 \pm 0,20$ & 0,10 \\
\hline $\mathrm{C} 20: 0$ & $0,30 \pm 0,01$ & $0,10 \pm 0,01$ & - & $0,40 \pm 0,01$ & $0,50 \pm 0,02$ & $0,30 \pm 0,02$ & $0,30 \pm 0,00$ & 0,20 \\
\hline C20:1 & $0,10 \pm 0,00$ & $0,10 \pm 0,00$ & - & $0,10 \pm 0,07$ & $0,80 \pm 0,09$ & $0,10 \pm 0,01$ & $0,30 \pm 0,11$ & 0,10 \\
\hline C20:5 & - & - & - & - & $6,50 \pm 0,02$ & $0,10 \pm 0,01$ & $0,10 \pm 0,00$ & 0,10 \\
\hline $\mathrm{C} 22: 0$ & - & - & - & - & $0,50 \pm 0,01$ & $0,10 \pm 0,00$ & $0,10 \pm 0,00$ & 0,10 \\
\hline C22:6 & - & - & - & - & $34,50 \pm 0,32$ & $0,60 \pm 0,08$ & $0,70 \pm 0,06$ & 0,70 \\
\hline $\mathrm{C} 24: 0$ & - & - & - & - & $1,30 \pm 0,05$ & $0,10 \pm 0,01$ & $0,10 \pm 0,00$ & 0,10 \\
\hline
\end{tabular}
2,9:3,4:1,5:2,0:0,2 
Namun demikian, komposisi asam lemak campuran ini menyerupai PLASI yang dihasilkan oleh Karabulut et al. (2007) dan Yadong dan Guicheng (2011). Sebagai tambahan, kandungan asam palmitat pada campuran tersebut telah memenuhi lemak ASI yaitu sebesar $20-30 \%$ (Tecelao et al., 2010). Sebagai pembanding, Yuhas et al. (2006) melaporkan bahwa lemak ASI pada ibu-ibu di negara Filipina mengandung asam dekanoat 2,4\%, asam laurat $13,8 \%$, asam miristat $12,1 \%$, asam palmitat $23,0 \%$, asam stearat $4,8 \%$ dan asam oleat 21,9\%. Yadong dan Guicheng (2011) melaporkan bahwa lemak ASI mengandung asam dekanoat $1,4 \%$, asam laurat $5,4 \%$, asam miristat $7,3 \%$, asam palmitat $26,5 \%$, asam stearat $9,5 \%$, asam oleat $35,5 \%$ dan asam linoleat $7,2 \%$. Selain itu, Daud et al. (2013) melaporkan bahwa lemak ASI mengandung asam laurat $8,4 \%$, asam miristat $7,6 \%$, asam palmitat $29,0 \%$, asam stearat $5,6 \%$, asam oleat $32,5 \%$ dan asam linoleat 7,5\%. Dari data-data tersebut menunjukkan bahwa campuran pada penelitian ini memiliki karakteristik yang menyerupai lemak ASI.

Titik leleh campuran minyak sebesar $44,2^{\circ} \mathrm{C}$ (Tabel 2), nilai ini relatif tinggi dan belum sesuai sebagai lemak pengganti susu karena sulit mencair. Oboh (2012) menyatakan bahwa lemak ASI memiliki profil pelelehan yang baik dan mencair sempurna pada suhu tubuh. Dengan demikian, penurunan titik leleh lemak campuran perlu dilakukan melalui modifikasi yaitu secara interesterifikasi. Interesterifikasi berguna untuk mengubah struktur asam lemak pada trigliserida yang menyebabkan perubahan titik leleh. Interesterifikasi secara enzimatis merupakan cara terbaik agar diperoleh lipida terstruktur yang dapat diatur perubahan asam lemaknya pada sn 1,3 atau sn 2. Dalam sintesis PLASI, beberapa katalis lipase yang digunakan adalah Lipozyme TL IM (Karabulut et al., 2007; Tecelao et al., 2010), Lipozyme RM IM (Nielsena et al., 2006; Tecelao et al., 2010) dan Novozyme 435 (Tecelao et al., 2010).

Interesterifikasi campuran minyak tidak mengubah komposisi asam lemak (Tabel 1). Hal ini di- sebabkan karena interesterifikasi hanya mengubah asam lemak pada trigliserida sehingga menyebabkan perubahan komposisi gliserida (monogliserida [MG], digliserida [DG] dan trigliserida [TG]). Perpindahan asil asam lemak juga menimbulkan terbentuknya asam lemak bebas (ALB). Gambar 1 menunjukkan bahwa campuran sebelum interesterifikasi mengandung ALB rendah $(0,56 \%)$ dan TG tinggi $(96,1 \%)$. Semakin meningkatnya waktu reaksi interesterifikasi menyebabkan kadar ALB meningkat sedangkan TG menurun dengan terbentuknya MG dan DG. Pada waktu 4 jam, ALB, MG dan DG yang terbentuk relatif rendah sementara $T G$ relatif tinggi dibandingkan pada waktu yang lainnya dengan nilai masing-masing 7,$1 ; 6,7 ; 1,7$ dan $84,5 \%$.

Titik leleh produk setelah interesterifikasi juga mengalami perubahan (menurun yang menandai terjadinya perubahan asam lemak pada struktur trigliserida (Tabel 2). Setelah waktu reaksi 4 jam, titik leleh meningkat hingga waktu 8 jam kemudian terjadi penurunan kembali hingga 24 jam namun penurunannya tidak drastis dengan kisaran sebesar $27-28^{\circ} \mathrm{C}$. Selain titik leleh, kandungan lemak padat produk PLASI juga mengalami penurunan setelah interesterifikasi (Tabel 3). Pada waktu reaksi 4 jam, PLASI memiliki kandungan lemak padat lebih rendah dibandingkan waktu 2 jam namun relatif sama pada waktu interesterifikasi lainnya. Produk PLASI yang dihasilkan memiliki kandungan lemak padat pada temperatur $30^{\circ} \mathrm{C}$ sebesar $1,0-1,5 \%$ sedangkan pada suhu $35^{\circ} \mathrm{C}$ seluruh lemak mencair $(0 \%)$.

Tabel 2. Titik leleh campuran minyak selama interesterifikasi

\begin{tabular}{cc}
\hline Waktu Interesterifikasi (Jam) & Titik Leleh $\left({ }^{\circ} \mathrm{C}\right)$ \\
\hline Awal & $44,20 \pm 0,14$ \\
2 & $32,00 \pm 0,28$ \\
4 & $28,00 \pm 0,00$ \\
6 & $28,40 \pm 0,00$ \\
8 & $28,60 \pm 0,28$ \\
16 & $27,20 \pm 0,14$ \\
24 & $27,40 \pm 0,14$ \\
\hline
\end{tabular}

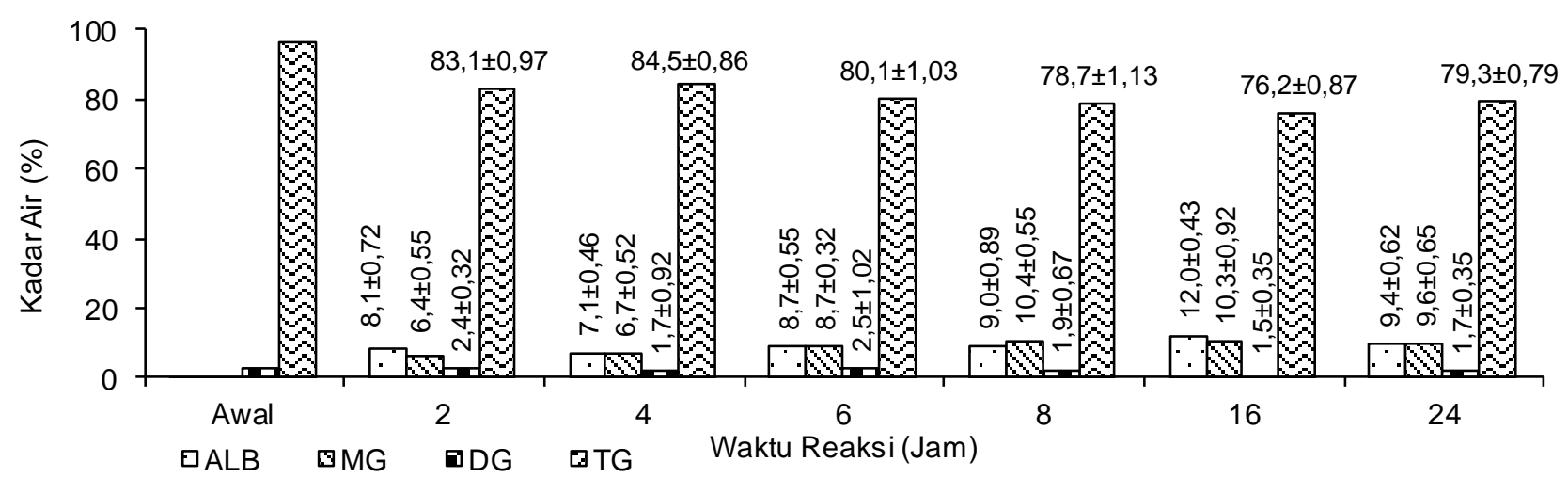

Gambar 1. Komposisi gliserida dan asam lemak bebas pensubstitusi lemak air susu ibu (PLASI) selama interesterifikasi 
Tabel 3. Kandungan lemak padat (\%) pensubstitusi lemak air susu ibu (PLASI) selama interesterifikasi

\begin{tabular}{|c|c|c|c|c|c|c|c|}
\hline \multirow{2}{*}{$\begin{array}{c}\text { Temperatur } \\
\left({ }^{\circ} \mathrm{C}\right)\end{array}$} & \multicolumn{7}{|c|}{ Waktu Interesterifikasi (Jam) } \\
\hline & Aw al & 2 & 4 & 6 & 8 & 16 & 24 \\
\hline 10 & $44,00 \pm 0,25$ & $36,30 \pm 0,15$ & $36,00 \pm 0,21$ & $34,40 \pm 0,28$ & $34,40 \pm 0,32$ & $32,70 \pm 0,29$ & $31,50 \pm 0,12$ \\
\hline 20 & $23,10 \pm 0,31$ & $14,90 \pm 0,25$ & $13,50 \pm 0,25$ & $11,70 \pm 0,23$ & $11,70 \pm 0,27$ & $11,20 \pm 0,25$ & $11,50 \pm 0,13$ \\
\hline 25 & $15,909 \pm 0,12$ & $7,40 \pm 0,17$ & $5,90 \pm 0,11$ & $4,50 \pm 0,15$ & $5,20 \pm 0,14$ & $4,90 \pm 0,14$ & $4,50 \pm 0,09$ \\
\hline 30 & $12,90 \pm 0,15$ & $3,50 \pm 0,12$ & $1,60 \pm 0,10$ & $0,90 \pm 0,05$ & $0,80 \pm 0,03$ & $0,50 \pm 0,05$ & $0,30 \pm 0,03$ \\
\hline 35 & $8,07 \pm 0,05$ & $0,80 \pm 0,10$ & $0,10 \pm 0,00$ & - & - & . & - \\
\hline 40 & $7,707 \pm 0,09$ & $0,40 \pm 0,08$ & - & - & - & - & - \\
\hline
\end{tabular}

Gambar 1 dan Tabel 2 menunjukkan bahwa waktu interesterifikasi selama 4 jam pada suhu $60^{\circ} \mathrm{C}$ merupakan kondisi optimum untuk mensintesis PLASI dari campuran stearin sawit, minyak inti sawit, minyak kedelai, minyak zaitun dan minyak ikan tuna. Kondisi ini sama dengan yang digunakan oleh Karabulut et al. (2007) yaitu selama 4 jam. Produk ini telah memenuhi persyaratan lemak susu untuk manusia dikarenakan mudah mencair pada suhu tubuh sebagaimana yang telah dinyatakan oleh Oboh (2012).

\section{Mikroenkapsulasi PLASI}

Mikroenkapsulasi PLASI dilakukan melalui penyemprotan emulsi minyak dan air menggunakan alat pengeringan semprot. Air pada emulsi akan terevaporasi setelah mengalami kontak dengan udara pengering dan kemudian terjadi pemisahan partikel kering (Elisabet et al., 2008). Mikrokapsul yang dihasilkan berupa bubuk dan di dalamnya terperangkap lemak yang larut dalam air. Perlakuan jenis bahan penyalut mempengaruhi efisiensi enkapsulasi, perolehan enkapsulasi, kadar minyak tidak tersalut, kelarutan mikrokapsul dalam air dan kadar airnya. Mikrokapsul diharapkan memiliki efisiensi penyalutan yang baik, dimana zat aktif secara sempurna tersalut oleh bahan penyalut (Muchtadi et al., 2015). Gambar 2 menunjukkan bahwa susu skim A menghasilkan efisiensi enkapsulasi lebih tinggi $(46,0-75,5 \%)$ dibandingkan susu skim B $(6,4-$ $11,2 \%)$. Selain itu, susu skim A menghasilkan perolehan mikrokapsul lebih tinggi $(86,0-99,0 \%)$ dibandingkan susu skim B $(12,4-20,4 \%)$. Hal ini disebabkan oleh kelarutan susu skim B dalam air lebih rendah $(74,5 \%)$ dibandingkan susu skim A $(90,7 \%)$. Konsentrasi PLASI sebanyak $25 \%$ memberikan efisiensi enkapsulasi dan perolehan enkapsulasi lebih besar dibandingkan dengan konsentrasi 30, 15 dan $20 \%$. Hal ini diduga disebabkan oleh pada konsentrasi tersebut interaksi antara bahan penyalut dengan minyak cukup optimal sehingga proses enkapsulasi lebih baik. Elisabeth et al. (2003) menghasilkan mikroenkapsulat minyak sawit merah dengan perolehan mikrokapsul efisiensi mikroenkapsulat yang berbeda untuk setiap bahan penyalut yaitu maltodekstrin dan padatan sirup jagung sebesar 33-35\%, $\beta$-cyclodekstrin dan laktosa masingmasing sebesar $97 \%$ dan $99 \%$ sedangkan isolat protein kedelai dan gum arab sebesar $75 \%$. Yanuar et al. (2007) melaporkan efisiensi mikroenkapsulasi minyak buah merah 20, 30 dan $40 \%$ masing-masing sebesar 74,$84 ; 70,16$ dan $55,79 \%$. Sementara itu, Supriyadi dan Rujita (2013) memperoleh efisiensi mikroenkapsulasi minyak atsiri lengkuas dengan bahan penyalut maltodekstrin pada nisbah 1:8, 1:10 dan 1:12 masing-masing adalah 51,56; 53,96 dan $55,40 \%$. Muchtadi et al. (2015) memperoleh efisiensi mikroenkapsulasi minyak sawit sebesar $55,9-68,5 \%$ dengan menggunakan bahan penyalut maltodekstrin, gum arab dan gelatin.

Semakin banyak jumlah PLASI yang digunakan cenderung menghasilkan kadar minyak tidak tersalut lebih tinggi. Hal ini disebabkan oleh bahan penyalut kurang optimal atau kurang homogen berinteraksi dengan minyak sehingga minyak berada di permukaan mikrokapsul. Gambar 3 menunjukkan bahwa susu skim B cenderung memberikan kadar minyak tidak tersalut lebih rendah kecuali pada konsentrasi PLASI 30\% dibandingkan susu skim A. Hal ini diduga disebabkan oleh susu skim B memiliki kelarutan yang rendah sehingga proses homogenisasi antara minyak dengan bahan penyalut kurang optimal. Menurut Muchtadi et al. (2015) bahwa mikrokapsul diharapkan memiliki kandungan minyak tidak tersalut serendah mungkin. Yuliani et al. (2007) menambahkan bahwa adanya minyak tidak tersalut akan terekspos pada kondisi lingkungan sekitarnya dan dapat mengalami kerusakan. Kadar minyak tidak tersalut yang diperoleh penelitian ini berkisar antara 11,5-28,0\%. Muchtadi et al. (2015) memperoleh kadar minyak tidak tersalut berkisar $9-13 \%$ pada mikrokapsul minyak sawit. Sementara, Yuliani et al. (2007) memperoleh kadar minyak tidak tersalut relatif rendah $0,15-0,19 \%$. Mikrokapsul sebaiknya memiliki kelarutan yang tinggi dalam pelarut yang umum digunakan seperti air (Khasanah et al., 2015). Mikrokapsul menggunakan susu skim $A$ dan susu skim B yang dicampurkan dengan laktosa dan maltodekstrin memiliki kelarutan dalam air relatif rendah yaitu berkisar 41,5-69,2\% (suhu air 28$30^{\circ} \mathrm{C}$ ) dan $59,0-82,9 \%$ (suhu air $50-55^{\circ} \mathrm{C}$ ) (Gambar 4). Kelarutan mikrokapsul menggunakan susu skim A relatif lebih tinggi dibandingkan susu skim B. Usmiati et al. (2010) menyatakan bahwa semakin banyak susu dalam bahan pengkapsul dan dengan pemanasan yang tinggi dapat menyebabkan penurunan tingkat kelarutan mikrokapsul karena terdenaturasinya protein dalam susu sehingga mempengaruhi tingkat kelarutan. 


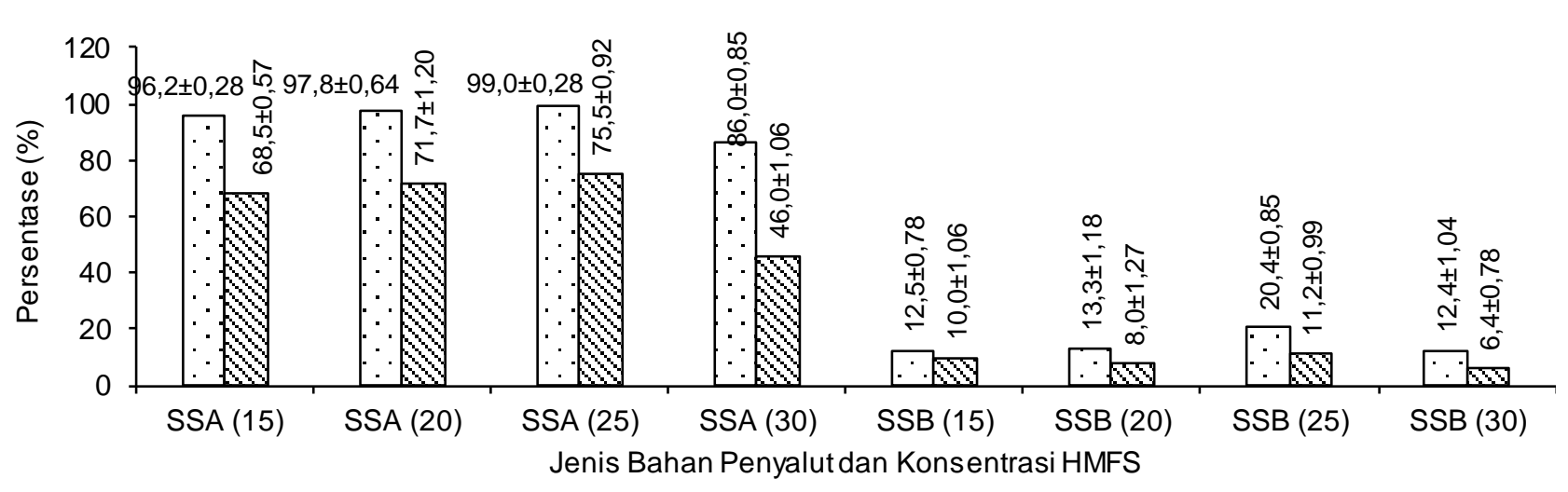

$\square$ Perolehan Mikrokapsul (\%) @Efisiensi Enkapsulasi (\%)

Keterangan: SSA = susu skim A, SSB = susu skim B

Gambar 2. Perolehan dan efisiensi enkapsulasi terhadap jenis bahan penyalut dan konsentrasi pensubstitusi lemak air susu ibu (PLASI)

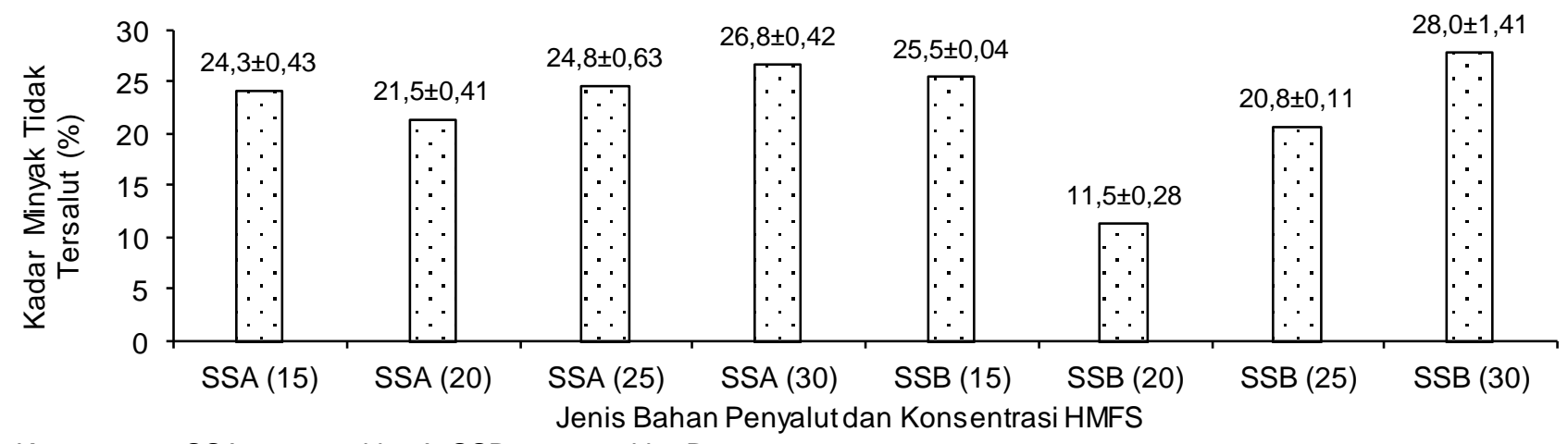

Keterangan: SSA = susu skim A, SSB = susu skim B

Gambar 3. Kadar minyak tidak tersalut pada mikrokapsul

Khasanah et al. (2015) menghasilkan mikrokasul menggunakan maltodekstrin, gum arab dan susu skim dengan kelarutan sebesar 94,4-98,1\%. Muchtadi et al. (2015) menyatakan bahwa penggunaan enkapsulan yang memiliki karakteristik larut air maka mikroenkapsulat yang dihasilkan memiliki kelarutan yang tinggi. Dengan demikian, rendahnya kelarutan dalam air mikrokapsul PLASI diduga disebabkan oleh jenis dan kualitas bahan penyalut khususnya kelarutannya dalam air. Uji kelarutan maltodekstrin dan laktosa diperoleh bahwa kedua bahan ini memiliki kelarutan yang baik di dalam air. Kenyon dalam Khasanah et al. (2015) juga menyatakan bahwa maltodekstrin dapat larut dengan sempurna dalam air dingin dan semakin tinggi derajat konversi pati menjadi dekstrosa (dextrose equivalency, DE) maka kelarutannya semakin tinggi. Rendahnya kelarutan dalam air bahan penyalut susu skim yang digunakan pada penelitian ini disebabkan adanya bahan yang tidak mudah larut dalam air seperti tepung. Susu skim B memiliki bahan yang tidak mudah larut dalam air lebih banyak dibandingkan susu skim $A$. Hal ini diduga yang menyebabkan efisiensi enkapsulasi menggunakan susu skim B sangat rendah seperti yang ditunjukkan pada Gambar 2. Ketika bahan penyalut tidak mudah larut dalam air maka penyalutan PLASI tidak sempurna terjadi karena lemak diemulsikan dalam air. Kadar air merupakan parameter yang menentukan kualitas mikrokapsul. Kadar air yang rendah dapat mencegah tumbuhnya mikroba yang dapat merusak produk (Khasanah et al., 2015). Kadar air produk mikrokapsul PLASI berkisar antara 1,85-5,30\%. Gambar 5 menunjukkan bahwa semakin tinggi konsentrasi PLASI menghasilkan kadar air produk lebih rendah. Usmiati et al. (2010) menambahkan bahwa semakin tinggi jumlah susu dalam pengkapsul maka semakin rendah kadar air mikrokapsul yang dihasilkan. Nilai ini telah memenuhi kadar air yang baik untuk produk mikrokapsul. Kisaran kadar air untuk produk mikrokapsul yang diperoleh dari pengering semprot sebesar 2$6 \%$ (Yuliani et al., 2007). Frascareli et al. (2012) menambahkan bahwa suhu inlet yang kurang dari $175^{\circ} \mathrm{C}$ akan menghasilkan produk dengan kadar air tinggi sementara di atas $175^{\circ} \mathrm{C}$ maka kadar air rendah. Hal senada juga dilaporkan oleh Yuliani et al. (2007) dan Mardaningsih (2012) bahwa suhu inlet pengering semprot mempengaruhi kadar air dari produk, semakin tinggi suhu inlet pengering semprot, maka akan semakin rendah kadar airnya. Muchtadi et al. (2015) melaporkan bahwa kadar air yang diperoleh dari mikrokapsul minyak sawit sebesar $0,88-1,85 \%$. 


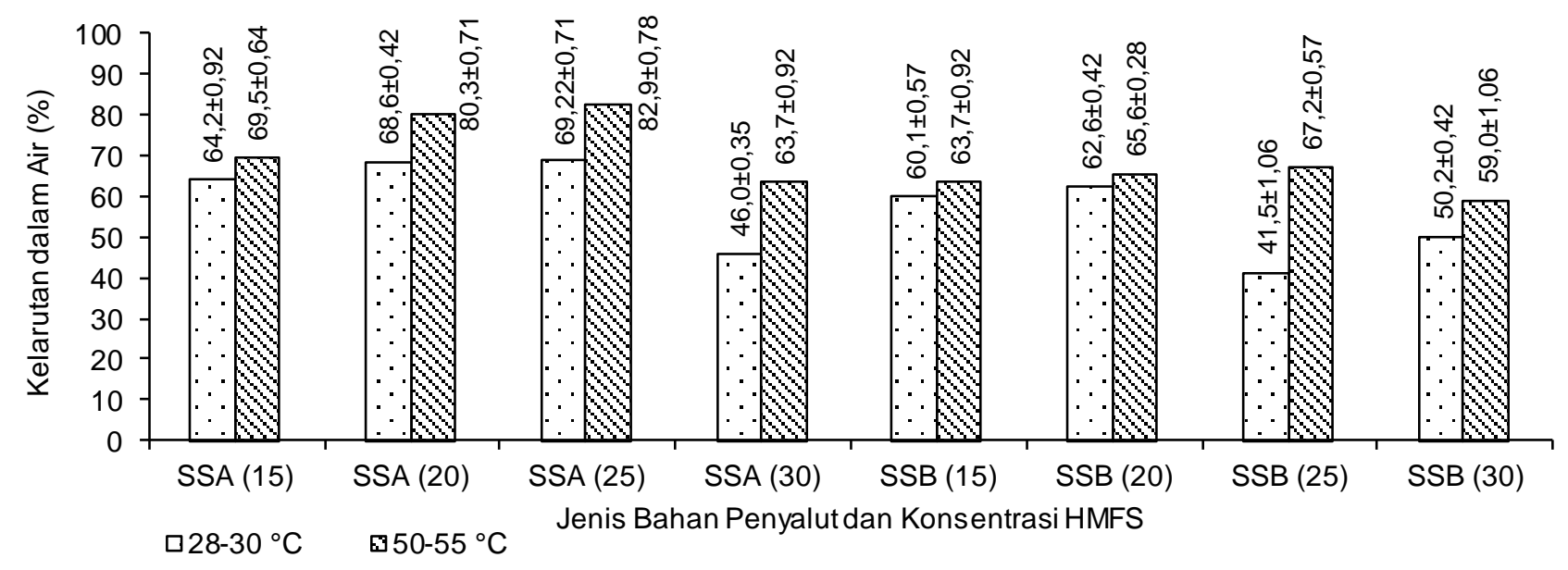

Keterangan: $\mathrm{SSA}=$ susu skim $\mathrm{A}, \mathrm{SSB}=$ susu skim $\mathrm{B}$

Gambar 4. Kelarutan dalam air mikroenkapsulat

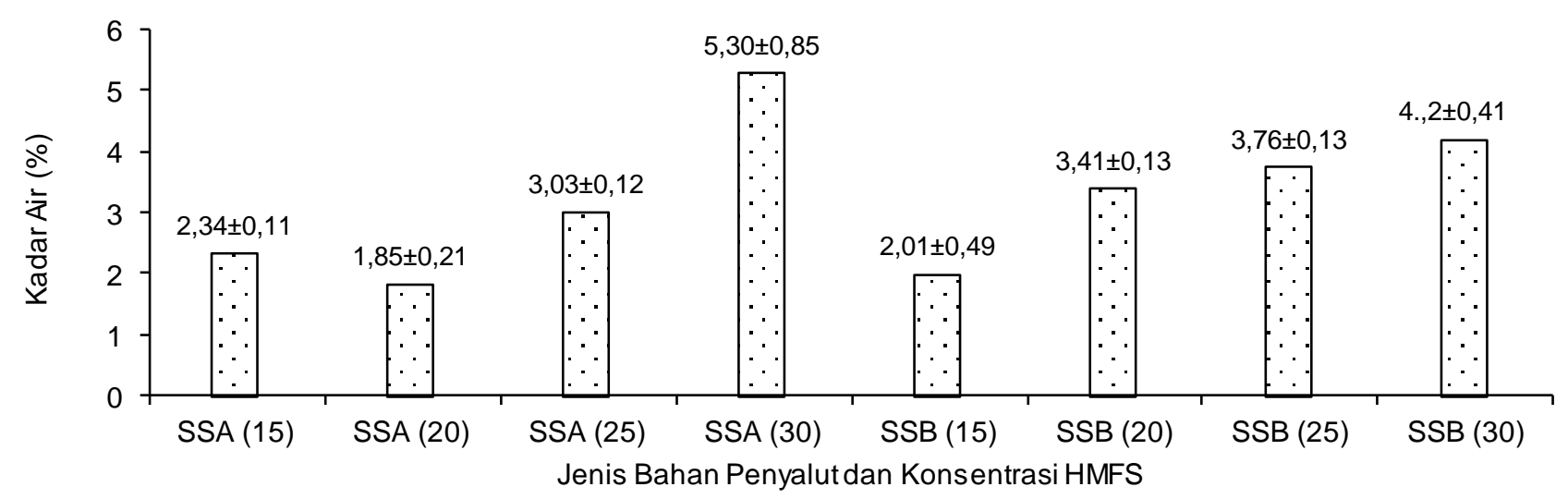

Keterangan: SSA = susu skim $A, S S B=$ susu skim B

Gambar 5. Kadar air mikroenkapsulat

\section{KESIMPULAN}

Interesterifikasi campuran stearin sawit, minyak inti sawit, minyak kedelai, minyak zaitun dan minyak ikan tuna pada nisbah 2,9:3,4:1,5:2,0:0,2 menggunakan enzim lipase dapat menghasilkan PLASI. Interesterifikasi campuran tersebut dapat menurunkan titik leleh dan kandungan lemak padat. Peningkatan waktu interesterifikasi dapat meningkatkan kadar ALB namun menurunkan TG. Mikroenkapsulasi PLASI menggunakan bahan penyalut susu skim yang berbeda kelarutan dalam air dapat mempengaruhi kualitas mikrokapsul meliputi perolehan mikrokapsul, efisiensi enkapsulasi, kadar air dan kelarutannya dalam air. Mikroenkapsulasi PLASI sebanyak 25\% menggunakan matriks susu skim, maltodekstrin dan laktosa menghasilkan perolehan mikrokapsul dan efisiensi enkapsulasi yang tinggi dibandingkan konsentrasi 15, 20 dan 30\%.

\section{DAFTAR PUSTAKA}

[AOAC] Association of Official Agricultural Chemists. 1997. Method of Analysis of Association of Official Analytical Chemist. Washington DC (USA): AOAC Inc.

[AOCS] American Oil Chemist's Society. 1998. Official Methods and Recommended Practices of the American Oil Chemists' Society". $4^{\text {th }}$ Ed. American Oil Chemists' Society. Champaign. IL.

Daud AZ, Esa NM, Azlan A, Chan YM. 2013. The trans fatty acid content in human milk and its associated with maternal diet among lactating mothers in Malaysia. Asia Pac J Clin Nutr 22: 431-442. DOI: 10.6133/apjcn.2013.22.3.09.

Djajasoepena S, Suprijana O, Diana S, Pratomo U, Puspitasari S. 2015. Production of human milk fat replacement rich of 1,3-dioleoyl-2-palmitoilglycerol from enzymatic interesterification tripalmitin, ethyl oleate and mixture of vco, soybean 
oil and fish oil. Procedia Chem 16: 384-391. DOI: 10.1016/j.proche.2015.12.068.

Elisabeth J, Siahaan D, Andarwulan N. 2003. Mikroenkapsulasi minyak makan merah untuk produk suplemen dan fortifikan pangan. I Penelitian Kelapa Sawit 16: 13-26.

El-Salam BAA. 2015. Effect of milk fat replacement with vegetable oil and or whey protein concentrate on microstructure, texture and sensory characteristics of fresh soft cheese. Int J Dairy Sci 10: 117-125. DOI: 10.3923/ijds. 2015.117. 125.

Fardiaz D. 1992. Petunjuk Laboratorium Teknik Analisis Sifat Kimia dan Fungsional Komponen Pangan. Bogor: PAU Pangan dan Gizi IPB. 1139.

Frascareli EC, Silva VM, Tonon RV, Hubinger MD. 2012. Effect of process conditions on the microencapsulation of coffe oil by spray drying. Food Bioprod Process 90: 413-424. DOI: 10. 1016/j.fbp.2011.12.002.

Goedhart AC, Bindles JG. 1994. The composition of human milk as a model for the design of infant formulas: recent findings and possible applications. Nutr Res Rev 7: 1-23. DOI: 10. 1079/ NRR19940004.

Hasibuan HA. 2012. Kajian mutu dan karakteristik minyak sawit serta produk fraksinasinya. J Standardisasi 14: 13-21.

Hasibuan HA, Siahaan D, Sunarya. 2012. Kajian karakteristik minyak inti sawit Indonesia dan produk fraksinasinya terkait dengan amandemen standar codex. J Standardisasi 14: 98104.

Hasibuan HA, Siahaan D. 2014. Review standar minyak goreng sawit diperkaya karoten terkait fortifikasi vitamin a sebagai revisi SNI 031-37412002. J Standardisasi 16: 65-76.

Karabulut IS, Turan, Vural H. 2007. Human milk fat substitute produced by enzymatic interesterification of vegetable oil blend. Food Technol Biotech 45: 434-438.

Karow S, Suparmo, Hastuti P, Utami T. 2012. High lauric human milk fat analog prepared from palm stearin and coconut oil by enzymatic interesterification. Afr J Food Sci 6: 441-448. DOI: 10.589 7/AJFS12.090.

Khasanah LU, Anandhito BK, Rachmawaty T, Utami, Manuhara GJ. 2015. Pengaruh nisbah bahan penyalut maltodekstrin, gum arab, dan susu skim terhadap karakteristik fisik dan kimia mikrokapsul oleoresin daun kayu manis (Cinnamomum burmannii). J Aghritech 35: 414421.
Koo WWK, Hockman EM, Dow M. 2006. Palm olein in the fat blend of infant formulas: effect on the intestinal absorption of calcium and fat, and bone mineralization. J Am Coll Nutr 25: 117122.

Levin M. 2006. Pharmaceutical Process Scaled Up Second Edition. USA: Taylor \& Fracis Group, LLC. 70 \& 443.

Lubary M, Hofland GW, ter Horst JH. 2011. The potential of milk fat for the synthesis of valuable derivatives. Eur Food Res Technol 232: 1-8. DOI: 10.1007/s00217-010-1387-3.

Maduko CO, Akoh CC, Park YW. 2007. Enzymatic interesterification of tripalmitin with vegetable oil blends for formulation of caprine milk infant formula analogs. J Dairy Sci 90: 594-601. DOI: 10.3168/jds.S0022-0302(07)71542-4.

Mardaningsih F, Andriani MAM, Kawiji. 2012. Pengaruh konsentrasi etanol dan suhu spray dryer terhadap karakteristik bubuk klorofil daun alfaalfa dengaan menggunakan binder maltodekstrin. J Teknosains Pangan 1: 110-117.

Muchtadi TR, Ilma AN, Hunaefi D, Yuliani S. 2015. Kondisi homogenisasi dan prapeningkatan skala proses mikroenkapsulasi minyak sawit. J Teknol Ind Pert 25: 248-259.

Nielsena NS, Yang TK, Xu XB, Jacobsen C. 2006. Production and oxidative stability of human a human milk fat substitute produced from lard by enzyme technology in a pilot packed-bed reactor. Food Chem 94: 53-60. DOI: 10.1016/j. foodchem.2004.10.049.

Nikkhah A. 2012. Equidae milk promises substitutes for cow and human breast milk. Turk J Vet Anim Sci 36: 470-475. DOI: 10.3906/vet-1105-10.

Oboh FOJ. 2012. Palm oils in dairy substitutes. Afr Sci 13: 99-108.

Puligundla P, Variyar PS, Ko S, Obulam VSR. 2012. Emerging trends in modification of dietary oils and fats, and health implications - a review. Sains Malaysiana 41: 871-877.

Purwanti M, Sudarwanto M, Rahayu WP, Sanjaya AW. 2009. Pengaruh berbagai kondisi preparasi dan penyimpanan susu formula pada pertumbuhan spora Bacillus cereus dan Clostidium perfringens. J Teknol Industri Pangan 20: 1-8.

Sahin N, Akoh CC, Karaali A. 2005a. Enzymatic production of human milk fat substitutes containning gamma linoleic acid: optimization of reactions by response surface methodology. J Am Oil Chem Soc 82: 549-557.

Sahin N, Akoh CC, Karaali A. 2005b. Lipasecatalized acidolysis of tripalmitin with hazelnut oil fatty acids and stearic acid to produce human 
milk fat substitutes. J Agr Food Chem 53: 57795783. DOI: 10.1021/jf050465e.

Sahin N, Akoh CC, Karaali A. 2006. Human milk fat substitutes containing omega-3 fatty acids. J Agr Food Chem 54: 3717-3722. DOI: 10.1021/ jf053103f

Saphier O, Blumenfeld J, Silberstein T, Tzor T, Burg A. 2013. Fatty acid composition of breastmilk of Israeli mothers. Indian Pediatr 50: 1044-1046.

Siahaan D, Elisabeth J, Haryati T. 2008. Sintesis lipida terstrukktur yang rendah kalori berbasis minyak sawit. J Penel Kelapa Sawit 16: 101 . 117.

Supriyadi, Rajita AS. 2013. Karakteristik mikrokapsul minyak atsiri lengkuas dengan maltodekstrin sebagai enkapsulan. J Teknol Industri Pangan 24: 201-208. DOI: 10.6066/jtip.2013.24.2.201.

Tecelao C, Silva J, Dubreucq E, Ribeiro $\mathrm{MH}$, Ferreira-Dias S. 2010. Production of human milk fat substitutes enriched in omega-3 polyunsaturated fatty acids using immobilized commercial lipases and Candida parapsilosis lipase/acyltransferase. J Mol Catalysis B-Enzym
65: 122-127. DOI: 10.1016/j.molcatb.2010.01. 026.

Usmiati S, Yuliani S, Noor E. 2010. Aktivitas hambat bakteri patogen oleh serbuk bakteriosin asal lactobacillus sp. galur SCG 1223. J Teknol Ind Pert 21: 102-112.

Yadong Z, Guicheng H. 2011. Advance on production of human milk fat substitutes (HMFS). J North Agr Univ 18: 92-96. DOI: 10.1016/S1006-8104(12)60016-6.

Yanuar W, Widjanarko SB, Wahono T. 2007. Karakteristiki dan stabilittas antioksidan mikroenkapsulat minyak buah merah (Pandanus conoideus Lam) dengan bahan penyalut berbasis protein. J Teknol Pert 8: 127-135.

Yuhas R, Pramuk K, Lien EL. 2006. Human milk composition from nine countries varies most in DHA. Lipids 41: 851-858. DOI: 10.1007/s1145006-5040-7.

Yuliani S, Desmawarni, Harimurti N, Yulliani SS. 2007. Pengaruh laju alir umpan dan suhu inlet spray drying pada karakteristik mikrokapsul oleoresin jahe. J Pascapanen 4: 18-26. 